\title{
Review on Design and Development of Vegetable Cleaning Machine
}

\author{
Pranita Joshi $^{1}$, Dr K. S. Zakiuddin ${ }^{2}$, Dr.V.M.Sonde ${ }^{3}$ \\ ${ }^{I}$ Research Scholar, Priyadarshini College of Engineering, Nagpur, India, 440019 \\ ${ }^{2}$ Professor, Priyadarshini College of Engineering, Nagpur, India, 440019 \\ ${ }^{3}$ Assistant Professor, Priyadarshini College of Engineering, Nagpur, India, 440019
}

DOI: 10.46335/IJIES.2020.5.10.5

\begin{abstract}
The root vegetables like radish, carrot and potatoes, etc., after harvesting have to be free from dust the soil and clay particles before move them from one place to another place. basically Indian farmers pursue a traditional method of cleaning the carrots, radish in which the roots are washed in water from hands and feet. which take to be more time exhaust and requires many quantity of labors to work. This project is based on design of vegetable cleaning machine to clean the vegetable properly. This study deals with the design of vegetable cleaning machine. In this project we will be made CAD model of the machine and execute FEA on machine it will remove to know the accentuate and displacement.
\end{abstract}

Keywords- CAD model, FE Analysis

\section{I- INTRODUCTION}

W ashing of vegetables is vital step in any processing operation, which gives attractive and chemical free vegetables. The vegetables like potatoes, tomatoes, cabbage, carrots, radish, etc., after harvesting required to be cleaned from the dust partials before one place to another places. Basically more Indian farmers pursue a traditional method of cleaning the carrots, radish in which the roots are washed in water by hands and feet. There is required to design a revolving type vegetable cleaner that each farmer in India can use. Washing of root crops before selling it into the market, is an essential process, which reduces the surface microbial load, while removing the field soil, dust and even residual pesticides, which leads to the value addition of the produce at the farm level.
Contamination of vegetables is generally due to unsanitary cultivation and marketing practices. The bacteria and fungicide to link with the food if left unsanitized, can be dangerous for a people health point of view, because they can run to health hazard.
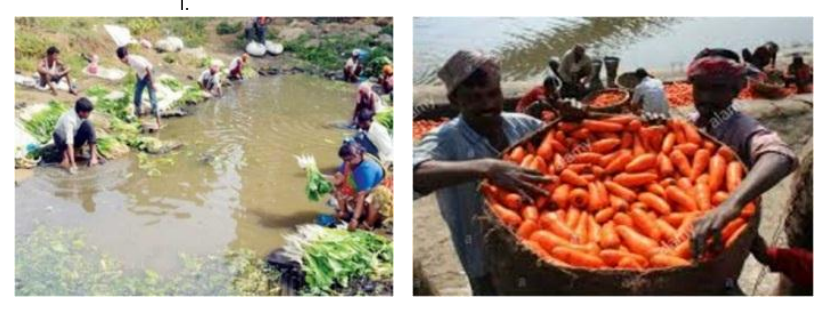

\section{II- AIM AND OBJECTIVES}

- To conceptualize a design for vegetable cleaner.

- To perform design calculations of vegetable cleaner.

- To perform CAD modeling of the concept design.

- To reduce labour requirement and time for vegetable cleaning.

- To clean the vegetable properly and make it free from unwanted particles.

- To make the delivery of vegetables from field to the market as quick as possible.

\section{III-RESEARCH METHODOLOGY}

- Data collection and literature study of vegetable cleaning

- Concept Design as per data collected and market requirement

- Design Calculations of conceptual design 
- $\quad$ CAD modeling of the concept design

- Structural Analysis and design optimization

- Result discussion

- Design finalization

\section{IV- PROBLEM DEFINITION}

Normally Indian farmers are following a traditional method of cleaning the vegetable i.e. washing it manually by hands or feet's which seems to be very time consuming and requires more number of labours to process. Many times farmers, directly bring the vegetables to the market for selling and do not sanitize the vegetables properly due to lack of time, a large quantity of unwanted particles may hold on tightly on its surface, when consumed may cause health hazards. So there is an essential requirement of Vegetable cleaner to clean the vegetables properly.

\section{V- LITERATURE REVIEW}

In this paper, A Prototype of fruit washer was designed for $50 \mathrm{~kg}$ capacity and performance was evaluated. Speed effect evaluated of different rotor 1466rpm, 1476rpm and $1486 \mathrm{rpm}$. On capacity and performance $20 \mathrm{~cm}$ (110 lit) effective depth of water obtained. For the execute appraisal of fruit washing potato used. The money ratio of potato washing by hand to machinery was 5.89:1. The average cost of mechanical washing was Rs. 24.80 per tonne. The charges of machine was Rs. $14,650 /$ - with electric motor. The outer dimensions of setup were 1000 × 560 × $750 \mathrm{~mm}$. The performance concluded that washing efficiency of machine varied between 96.36 to $98.18 \%$ for all the rotor's used for potato washing. The capacity of setup was varied between $340.87 \mathrm{~kg} \mathrm{hr}-1$ to $892.11 \mathrm{~kg} \mathrm{hr}-1$. The PI varied from 2.25 to 3.26 . The maximum PI of 3.26 obtained in potato for rotor $\mathrm{C}$ at $1486 \mathrm{rpm}$. R. N. Kenghe [1]. The present study is focused on designing and development of Automated root vegetable washer. The Automated Root vegetable washer is a setup which could serve in the agricultural fields. The vegetables like Radish, carrot and potatoes, etc. need to clean off from soil and clay particles after harvesting before transmitting them to market. Basically Indian Farmers chase a traditional work of cleaning the radish, carrots, in water by hands and feet. This study targets the detail of setup. The muddy cut and put inside the Root vegetable washing drum through an opening given on drum. Then the opening is closed using leather belts and locks. Provisions for pressurized water supply inside the Root Crop Washer have been made. The drum is then rotated by a motor and water under pressure is supplied in the drum. Due to the rotation of the drum and the continuous supply of water the soil and clay particles are removed off the root crops. The muddy water falls down through the slits provided in the drum. Hence cleaning the root vegetables and transporting them ready for the vegetable market. Ravdeep Singh [2]. This study outlines the design and fabrication of a small capacity root crop cleaning from computer aided model simulation to a prototype building. The process methods of mechanical designing, material selection, development and prototype building are objected. Prototype selected, through proper testing, has validated the efficiency in the cleaning of root vegetables. The primary objective of the root crop cleaning design was to fulfill the needs of the McGill Student- Run Ecological Garden by alleviating the processing impact of cleaning fresh root crop vegetables. A effective solution of conceptual design developed through computer modelling, design analysis and prototyping. A scaled model of washer with adequate improvement addressed with successful testing. A long term solution to the MSEG agricultural operation is the intention of large scale operation. Additionally, this project will serve as an alternative engineering design application for future students within the department of Bio resource Engineering .Michelle Choi [3]. Development of cost effective carrot washer operated mechanically is the objective of this article. To reduce the time and human resources for the operation .Operation constraints and design considerations include capacity ranging from $3 \mathrm{~kg}(6.6 \mathrm{lb})$ to $11 \mathrm{~kg}(24.5 \mathrm{lb})$, a reduced operation speed to prevent breakage and bruising, low flow rates and water pressures, small pieces retention, simple loading and unloading, savings of cost and time compared with manually operated washing systems, and operator safety. Carrot were separated from stems and leaves prior to washing in this system. There was no requirement for Food-grade washing. A Rotary nonimmersion cleaning system developed using a horizontal 208-L (55-gal) barrel supported at rollers drive and equipped with a low-pressure spray wand.J. A. Moos [4]. Root crops such as carrot grows on rough and coarse heavy soils. As these vegetables grow under the soil, cleaning the mud and dust is mandatory. Root crops are harvested manually with leaves to minimize damage during transport. They are well prone be contaminate with microbial actions, cracking damage, cuts, bruising etc. it is recommended to remove the soil particles as early as possible. As it cannot be left along with unwanted particles for a long period of time. 
It is mandatory to clean off the soil mud, particles which will reduce the physical appeal in the market and also aid in further processing. Relatively little information is available in the research literature on mechanical root vegetable washers for small farmers. Dawn C. P. Ambrose [5]. This study was done to design, fabricate and evaluate the performance that could attain a high efficiency of cleaning that is acceptable in the market, as well as to establish the maximum washing capacity of the device. The performance of this setup was also compared with manually operated washing for the following parameters: setup capacity, cost related to labor and ease of processing. Manually cleaning of root crops is a very difficult job for every person. Cleaning of soil and foreign particles from potato before weighing, grading and sorting is essential step. Washing potato tubers is the key process for freshness and higher price. To pay high price for the fresh potato is not issue for the consumer. Glaizalyn B. Batara [6]. This study deals with the washing of fruits. Washing of the fruits and root vegetables mostly done by manual processes. This process is inefficient and time consuming as it comprises a lot of drudgery. Hence, arises a need of mechanize this method for hygiene and ease of doing operation and maintenance. In this study, a conceptualize design of fruit washer developed to clean a variety of fruits based on shapes as round and spherical. Such fruits as apple, cashew, pineapple, pawpaw, orange and mango etc. The setup developed consist of feed hopper, roller brushes, stainless tank, top cover, water jet system, control valve, chain drive, bearings, main frame and discharge outlet. The machine has been developed with the locally available materials powered by $3 \mathrm{hp}$ electric motor. Test carried out on the machine successfully revealed that the washing efficiency and the machine capacity were $89.73 \%$ \& $480.57 \mathrm{~kg} / \mathrm{h}$ respectively for orange and $90.16 \% \& 326.63 \mathrm{~kg} / \mathrm{h}$ respectively for pineapples. A. A degbite [7] .A fruit cleaning setup was designed and developed considering the techno-economic status of the micro, small and medium scale farmers who are the intended for the setup. Considerations also comprise high efficiency and capacity. To ensure the quality stainless steel is used for the construction of setup. Additional consideration structural stability of setup by sufficient supports to the frame. The setup was designed with incorporating guards around the moving parts and components for safety, ergonomic value, and ease of operation and maintenance. The testing of machine for washing operation done using orange samples. In testing phase, the conveyor beltconveyed the fruits under high pressure jet spray to get rid of the attached foreign materials. The test result observed that the cleaning capacity was 0.0163 tones/h or 16.3 $\mathrm{kg} / \mathrm{h}$ and cleaning efficiency was $62.5 \%$. Powered through $1 \mathrm{hp}$ single phase gear electric motor, the machine has a production cost of USD 300 while all the construction materials were available locally. I. Oyeleke [8]. A vegetable cleaner can be constructed with the washing action of water jets, soaking chambers, or scrubber brushes. A cleaner that employs the water jets is similar to an ordinary household dishwasher and would be economical, reliable, and adaptable to many different types of fruits and vegetables. In this article two designs were proposed as variations on this dishwasher. Standard dishwasher type with stationary rack and rotating spray nozzles, and a carrousel-type washer with fixed nozzles and rotating rack. A household dish cleaner was modified with a holding rack and water jet system. Various standard nozzles tested on a spray table for intensity and uniformity. Potatoes were placed in the Fruit washer for specified period of time followed with a visual concept of the element of dirt washed off the potato. Cleaning quality was affected by varying distance between potato and nozzle, position and orientation in water. Nozzle type and soil type did not impact on the degree of cleaning. TOBY J. MENDENHALL [9]. Cleaning root vegetables on a small farm can be challenging to do well especially if there are time and weather constraints. In interior Alaska, root crops often mature at the time when the weather is turning cold and the rush to do a good job is challenged by cold temperatures, short period of time because other projects are pressing and limited number of workers because much of the work force is back at school. Earlier unwashed root crops were placed in plastic crates and washed by hosing crates down and while pouring the crop from one crate to another. It was an adequate but backbreaking job. Even a small farm ( $<5$ acre) can bring in several tons of root crops each fall and this process of washing such a large quantity of crops can be daunting. A backlog of unwashed crops can often pile up and some are rendered either unfit for sale or unfit for personal consumption. For these reasons we had looked into a mechanized way of washing root vegetables for several years. With a simple tool like a barrel washer, we would be able to quickly clean root crops more efficiently while increasing the quality and preserving the yield of the end product. Processing our crops in a shorter period would reduce the time "bottleneck" of our previous washing method. Less food would go to waste and production could be expanded to meet the demand of 
local produce in the community while increasing our profit margin. Mike Emers [10].In this study a prototype is designed to clean root crops in large volume and reduce any damage that may incur during the process. This setup has capacity to wash off one tote (18USgal) of produce in 5 minutes with only one operator. The prototype is developed with interchangeable pulleys to allow three speed settings to accommodate different shaped produced and even unstopped produce in batched or continuous mode. The setup has not only low maintenance, it is user friendly as well; no tools are required to change speeds. The designed setup is installed with casters and can be portable by one person. The driveshaft components are fabricated with stainless steel to avoid corrosion issues while other parts in assembly are painted. Solomon Fung [11].

\section{VI- PLAN OF WORK}

1. Data accumulation.

2. Literature survey.

3. CAD modeling of Vegetable cleaning machine

4. Analysis of Vegetable cleaning machine in FEA.

5. Result discussion.

6. Finalization of the design

\section{VII - ANALYSIS OF LITERATURE REVIEW}

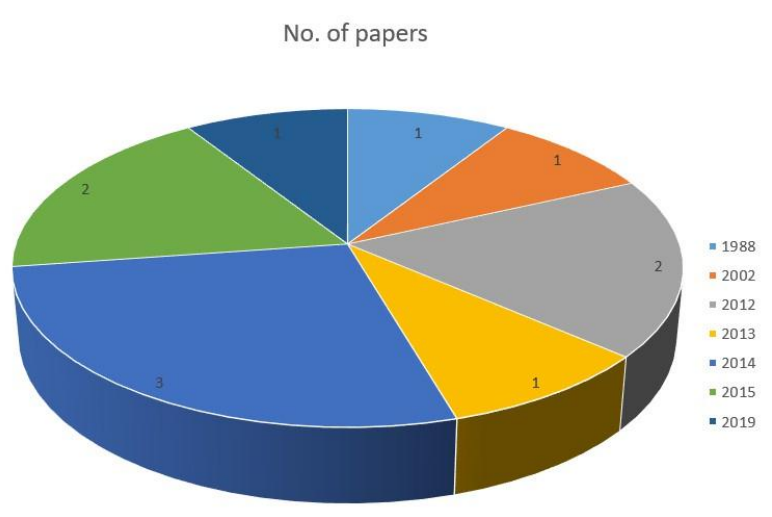

Graph 1: No. of Papers Publish in Year

VIII - SUMMARY OF VEGETABLE CLEANING MACHINE

\begin{tabular}{|l|l|l|}
\hline Technique & Author & \multicolumn{1}{|c|}{ Summary } \\
\hline $\begin{array}{l}\text { Mechanical } \\
\text { Fruit Washer }\end{array}$ & $\begin{array}{l}\text { R. N. } \\
\text { Kenghe }\end{array}$ & $\begin{array}{l}\text { Depth of water, speed of } \\
\text { rotor and quantity } \\
\text { of material are the }\end{array}$ \\
\hline
\end{tabular}

\begin{tabular}{|c|c|c|}
\hline & & $\begin{array}{l}\text { factors which vary the } \\
\text { capacity, performance } \\
\text { index and efficiency of } \\
\text { the machine. }\end{array}$ \\
\hline $\begin{array}{l}\text { Automatic } \\
\text { Root Crop } \\
\text { Washer }\end{array}$ & $\begin{array}{l}\text { Ravdeep } \\
\text { Singh } \\
\text { Ghuman }\end{array}$ & $\begin{array}{l}\text { The vegetables like } \\
\text { Radish, carrot and } \\
\text { potatoes, etc.need to } \\
\text { clean off from soil and } \\
\text { clay } \\
\begin{array}{l}\text { after particles } \\
\text { before } \\
\text { them to Markesting }\end{array}\end{array}$ \\
\hline $\begin{array}{l}\text { Root Crop } \\
\text { Washer }\end{array}$ & $\begin{array}{l}\text { Michelle } \\
\text { Choi }\end{array}$ & $\begin{array}{l}\text { The primary objective of } \\
\text { the root crop cleaning } \\
\text { design was to fulfil the } \\
\text { needs of the McGill } \\
\text { Student- Run Ecological } \\
\text { Garden by alleviating the } \\
\text { processing impact of } \\
\text { cleaning fresh root crop } \\
\text { vegetables. }\end{array}$ \\
\hline $\begin{array}{l}\text { Mechanical } \\
\text { Carrot } \\
\text { Washer }\end{array}$ & A. Moos & 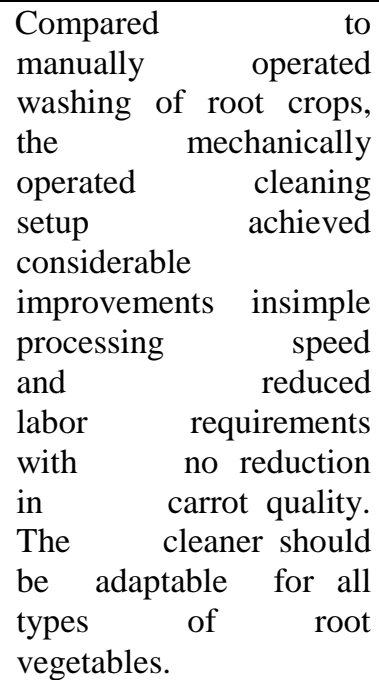 \\
\hline $\begin{array}{l}\text { Manually } \\
\text { Operated } \\
\text { Washer }\end{array}$ & $\begin{array}{l}\text { C. P. } \\
\text { Ambrose }\end{array}$ & $\begin{array}{l}\text { The designed manual } \\
\text { root crop cleaner was of } \\
10 \mathrm{~kg} \text { holding capacity } \\
\text { and it was witnessed } \\
\text { suitable for washing } \\
\text { root crops like carrot } \\
\text { and radish. }\end{array}$ \\
\hline $\begin{array}{l}\text { Barrel } \\
\text { Potato } \\
\text { Washer }\end{array}$ & $\begin{array}{l}\text { Galizalyn } \\
\text { B. Batara }\end{array}$ & $\begin{array}{l}\text { The machine has } \\
\text { a maximum } \\
\text { washing capacity of } \\
6.82 \text { kg/min and } \\
\text { maximum cleaning } \\
\text { efficiency } \\
\text { of } 93.82 \% \text {. Meanwhile, } \\
\text { the machine was } \\
\text { able to obtain the } \\
\text { minimum skinning } \\
\text { damage of } 3.51 \% \text {. }\end{array}$ \\
\hline Fruit & S. A. & A low capacity \\
\hline
\end{tabular}




\begin{tabular}{|c|c|c|}
\hline Washer & Adegbite & $\begin{array}{l}\text { fruit washer } \\
\text { developed and tested } \\
\text { for tomatoes and } \\
\text { oranges. } \\
\text { preliminary the } \\
\text { carried out on the } \\
\text { prototype indicate a } \\
\text { satisfactory } \\
\text { performance. } \\
\text { The machine capacity } \\
\text { for both products } \\
\text { indicates that the } \\
\text { equipment is suitable } \\
\text { for medium to large } \\
\text { scale operation. }\end{array}$ \\
\hline $\begin{array}{l}\text { Fruit } \\
\text { Washing } \\
\text { Machine }\end{array}$ & $\begin{array}{l}\text { F. I. } \\
\text { Oyeleke }\end{array}$ & $\begin{array}{l}\text { The study presents } \\
\text { the effect } \\
\text { pressurized sprays and } \\
\text { conveyor belts on root } \\
\text { crops and fruits. } \\
\text { Cleaning and washing of } \\
\text { fruits as a unit } \\
\text { operation in fruit } \\
\text { processing is of high } \\
\text { necessity and very } \\
\text { important in any fruit } \\
\text { process industries. }\end{array}$ \\
\hline $\begin{array}{l}\text { Vegetable } \\
\text { Washer }\end{array}$ & $\begin{array}{l}\text { Toby J. } \\
\text { Mendenhall }\end{array}$ & $\begin{array}{l}\text { After detail study, } \\
\text { design iterations and } \\
\text { laboratory experiments, } \\
\text { we have concluded } \\
\text { that a setup can be } \\
\text { built to meet the } \\
\text { food service industry. }\end{array}$ \\
\hline $\begin{array}{l}\text { Barrel } \\
\text { Wahser }\end{array}$ & Mike Emers & $\begin{array}{l}\text { By using the } \\
\text { barrel washer and } \\
\text { product time is } \\
\text { reduced, I would highly } \\
\text { recommend it for all } \\
\text { growers. The washer } \\
\text { has been so successful } \\
\text { and quick that other } \\
\text { nearby growers have } \\
\text { trucked their crops to us } \\
\text { for easy washing. }\end{array}$ \\
\hline $\begin{array}{l}\text { Vegetable } \\
\text { Barrel } \\
\text { Washer }\end{array}$ & $\begin{array}{l}\text { Solomon } \\
\text { Fung }\end{array}$ & $\begin{array}{l}\text { The automatic cleaning } \\
\text { setup reduces the } \\
\text { current number of } \\
\text { labour to allows } \\
\text { other workers to carry } \\
\text { out other farm } \\
\text { duties. The compact } \\
\text { design of the barrel } \\
\text { washer fits in } \\
\text { the allocated space } \\
\text { by the client at UBC } \\
\text { Farm and pneumatic } \\
\text { casters allow users to } \\
\text { easily relocate the unit. }\end{array}$ \\
\hline
\end{tabular}

\section{IX - CONCLUSION}

As per the requirement of vegetable cleaning machine will be designed with collecting data and design calculation of the machine. This project will be design to clean all vegetables On the basis of objective, data accumulated and design calculations a cad model of lifting mechanism will be modelled. After CAD modelling the Finite Element Modelling and Finite Element Analysis will be carried out by using FEA techniques to validate the Designed CAD model.

\section{REFERENCES}

[1] International Journal of Trend in Research and Development,"Design, Development and Testing of Small Scale Mechanical Fruit Washer"by R. N. Kenghe ,A. P. Magar and K. R. Kenghe, Department of agricultural ,MahatamFule Krishi Vidhyapith,Rahuri,India.

[2] IJRMET "Designing and Fabrication of Automatic Root Crop Washer" by Ravdeep Singh Ghuman, Rachit Khanna, SidhantSingla, Preetpal Singh, Harvinder Singh, School of Mechanical Engineering, Chitkara University, Punjab, India.

[3] Design of a Small Scale Root Crop Washer by Michelle Choi, Isabella Han, Kourosh Mohtashami.

[4] Small-Scale Mechanical Carrot Washer For Research Sample Preparation By A. Moos, D. D. Steele, D. C. Kirkpatrick .

[5] "Development of a manually operated root crop washer" Dawn C. P. Ambrose and S. J. K. Annamalai Central Institute of Agricultural Engineering, Regional Centre, Coimbatore-641 003, Tamil Nadu, India .

[6] "DESIGN, FABRICATION, AND PERFORMANCE EVALUATION OF A SMALLSCALE BARREL TYPE POTATO (SolanumTuberosumL.) WASHER" Glaizalyn B. Batara; Teresito G. Aguinaldo, Francisco D. Cuaresma, And Helen F. Gavino. College of Engineering, Central Luzon State University, Science City of Munoz, Nueva Ecija

[7] "Design and Development of Fruit Washer" S. A. Adegbite, S. K. Adeyemi, A. O. Komolafe, M. O. Salami, C. F. Nwaeche and A. A. Ogunbiyi. Journal of Scientific Research \& Reports 21(6): 1-11, 2018; Article no.JSRR.46041 ISSN: 2320-0227.

[8] "Development Of A Fruit Washing Machine" F. I. Oyeleke, A.M. Olaniyan, M. O. Sunmonu and S. K. OyeniyiDepartment of Agricultural and Biosystems Engineering,Faculty of Engineering and Technology, University of Ilorin, Nigeria. 